\section{Continuous High Rate Anaerobic Treatment of Oleic Acid Based Wastewater is Possible after a Step Feeding Start-Up}

ANA J. CAVALEIRO,

ANDREIA F. SALVADOR, JOANA I. ALVES, AND MADALENA ALVES*

Institute for Biotechnology and Bioengineering, Centre of Biological Engineering, University of Minho, Campus de Gualtar, 4710-057 Braga, Portugal

Received November 5, 2008. Revised manuscript received January 19, 2009. Accepted January 26, 2009.

Mineralization of a synthetic effluent containing $50 \%$ COD as oleic acid was achieved in a continuous anaerobic reactor at

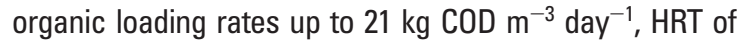
$9 \mathrm{~h}$, attaining $99 \%$ of COD removal efficiency and a methane yield higher than $70 \%$. A maximum specific methane production rate of $1170 \pm 170 \mathrm{mg}$ COD-CH $\mathrm{g} \mathrm{VS}^{-1}$ day $^{-1}$ was measured during the reactor's operation. A start-up strategy combining feeding phases and batch degradation phases was applied to promote the development of an anaerobic community efficient for long chain fatty acids (LCFA) mineralization. Through the start-up period, the methane yield increased gradually from $67 \%$ to $91 \%$, and LCFA accumulated onto the sludge only during the first 60 days of operation. For the first time, it is demonstrated that a step feeding start-up is required to produce a specialized and efficient anaerobic community for continuous high rate anaerobic treatment of LCFA-rich wastewater.

\section{Introduction}

Several technologies are described in the literature for the anaerobic treatment of oily effluents, namely upflow anaerobic sludge blanket (UASB) reactors (1-3), expanded granular sludge bed (EGSB) reactors $(4,5)$, and anaerobic filters (AF) (5) (Table 1). These systems do not always accomplish a desirable performance in terms of chemical oxygen demand (COD) removal and lipid conversion to methane, and this conversion tends to decrease with the increase of the organic loading rate (OLR) applied. Therefore, the treatment of this type of wastewater is generally performed at OLR lower than $10 \mathrm{~kg} \mathrm{COD} \mathrm{m}^{-3}$ day $^{-1}$ and still represents a challenge, continuously driven by emergent practical and fundamental knowledge (8). High rate anaerobic reactors for the treatment of complex lipid-rich wastewater represent a market niche that still needs to be filled and opens a place for research and development.

Several operational problems are described as the main causes for the difficult conversion of lipids to biogas, namely bacterial inhibition and sludge flotation and washout $(3,9,10)$. These problems result mostly from the accumulation of long chain fatty acids (LCFA) onto the microbial aggregates, by mechanisms of adsorption, precipitation and

* Corresponding author phone: +351 253604 417; fax: +351 253 678 986; e-mail: madalena.alves@deb.uminho.pt. entrapment $(9,11)$. Besides the potential metabolic inhibition, LCFA accumulation onto the sludge can create a physical barrier, with consequent limitations in the transport of substrates and products (11). However, the observation that large amounts of methane are produced when LCFA-loaded sludge is incubated in batch vials (12), suggested that efficient treatment of LCFA-rich wastewater can be accomplished, if a correct equilibrium between accumulation and degradation is assured. On the basis of these results, a discontinuous operation, specifically designed to promote LCFA accumulation during continuous feeding, and subsequent batch degradation of the biomass-associated substrate, was proposed as a strategy to achieve an efficient rate of methane production during the treatment of this type of wastewater (12). Nevertheless, in real high rate anaerobic treatment facilities, continuous treatment is preferable, due to the fact that wastewater is constantly generated and its energetic potential, in the form of biogas production, should not be wasted.

In this work, the anaerobic degradation of a synthetic oleic-acid rich wastewater was studied in a reactor operated in cycles during 213 days (by sequencing continuous feeding phases and batch reaction phases) and in continuous thereafter. Reactor performance, specific methanogenic activity, oleic acid toxicity, VFA, and LCFA accumulation were assessed throughout the experiment.

\section{Experimental Section}

Experimental Setup. An up-flow anaerobic column reactor was constructed in Plexiglas and was operated at constant temperature $\left(37 \pm 1^{\circ} \mathrm{C}\right)$. A Plexiglas settler was installed at the outlet of the reactor and the settled biomass was intermittently recycled three times per day, at a flow rate of $17 \mathrm{~L} \mathrm{day}^{-1}$ during $30 \mathrm{~min}$. A schematic representation of the experimental setup is presented in Figure 1 of the Supporting Information. The reactor was inoculated with $4.2 \mathrm{~L}$ of suspended biomass from a local municipal anaerobic sludge digester (33 $\mathrm{g} \mathrm{VS} \mathrm{L}^{-1}$ ). This biomass was previously exposed to fat, through an extended contact, since the fat removed in the beginning of the process in the municipal wastewater treatment plant was periodically introduced in the anaerobic digester. The reactor was fed with a synthetic dairy wastewater, composed of 50\% COD-skim milk and 50\% CODsodium oleate. This substrate was supplemented with macronutrients, micronutrients, and $\mathrm{NaHCO}_{3}$, as described elsewhere (13).

Routine Analysis. Performance was monitored by measuring biogas production, influent and effluent soluble COD (centrifuged $15 \mathrm{~min}$ at $15000 \mathrm{rpm}$ ), effluent volatile fatty acids (VFA), and effluent solids. COD and solids were determined according to Standard Methods (14). VFA were determined by HPLC (Jasco, Japan) using a Chrompack organic analysis column $(30 \times 6.5 \mathrm{~mm})$ and a mobile phase of $5 \mathrm{mM} \mathrm{H}_{2} \mathrm{SO}_{4}$ at a flow rate of $0.7 \mathrm{~mL} \mathrm{~min}^{-1}$. The column was set at $60{ }^{\circ} \mathrm{C}$, and the detection was made spectrophotometrically at $210 \mathrm{~nm}$. Biogas production was measured with a wet gas meter W-NK-0.5B (Shinagawa Corporation Factory, Japan) and the methane content was analyzed in a Pye Unicam GC-TCD gas chromatograph (Cambridge, England), using a Porapack Q (100-180 mesh) column. Helium was used as carrier gas $\left(30 \mathrm{~mL} \mathrm{~min}^{-1}\right)$ and the temperatures of the injection port, column, and detector were 110,35 , and $110^{\circ} \mathrm{C}$, respectively. The amount of methane produced was converted to its COD equivalent $\left(\mathrm{g} \mathrm{COD}-\mathrm{CH}_{4}\right)$ and methane yields were expressed as the ratio (\%) between the methane-COD produced and the 
TABLE 1. Performance of Anaerobic Systems for the Treatment of Oily Wastewater

\begin{tabular}{|c|c|c|c|c|c|}
\hline wastewater & reactor & $\begin{array}{c}\mathrm{OLR} \\
\left(\mathrm{kg} \mathrm{COD} \mathrm{m}^{-3} \text { day }^{-1}\right)\end{array}$ & $\begin{array}{l}\text { COD removal } \\
\text { efficiency (\%) }\end{array}$ & $\begin{array}{l}\text { methane } \\
\text { yield }(\%)\end{array}$ & ref \\
\hline food industry & UASB & 8 & 89 & 50 & 3 \\
\hline LCFA mixture $^{a}+$ glucose & CSTR + UASB & $<3$ & 60 & 36 & 2 \\
\hline fish processing & UASB & 8 & 92 & 47 & 6 \\
\hline sodium oleate + skim milk & $\mathrm{AF}$ & 12 & 80 & 25 & 5 \\
\hline \multirow[t]{2}{*}{ LCFA mixture $^{b}$} & EGSB & 4 & 69 & 9 & 4 \\
\hline & & 8 & 44 & 7 & \\
\hline \multirow[t]{2}{*}{ diluted cream } & EGSB & 8 & 80 & 45 & 7 \\
\hline & & 15 & 57 & 35 & \\
\hline
\end{tabular}

COD removed (eq 3 of the Supporting Information). During the operation in cycles (Period I), the contribution of the methane formed in each phase (feeding phase and reaction phase) relatively to the total amount produced in each cycle was also calculated and designated by "phase to cycle methane production ratio" (eq 2 of the Supporting Information). Specific methane production rates were calculated during the reactor's operation considering the methane production rate (g COD- $\mathrm{CH}_{4}$ day $^{-1}$ ) and the levels of VS measured periodically inside the reactor.

Sampling. A total of 18 samples were collected during the experiment, 9 during Period I and 9 during Period II of operation, as detailed in Table 1 of the Supporting Information. Complete mixture of the reactor's content was promoted and samples were collected through the third sampling port (Figure 1 of the Supporting Information). All samples were characterized in terms of long chain fatty acids accumulation and volatile solids content. Samples 1, 7, 9, and 18 were also characterized in terms of specific methanogenic activity (SMA) in the presence of acetate and $\mathrm{H}_{2} / \mathrm{CO}_{2}$. The influence of sodium oleate, in concentrations up to $900 \mathrm{mg} \mathrm{L}^{-1}$, on the acetoclastic activity was evaluated in batch assays performed with samples 1 and 9.

Long Chain Fatty Acids Quantification. Samples were centrifuged for separation between liquid and solid phases. Saturated and unsaturated LCFA from C12 to C18, present in the liquid phase or associated to the biomass (solid phase), were extracted and quantified according to the method described by Neves et al. (15). Free fatty acids present in the samples were esterified with propanol in acid medium at high temperature $\left(100{ }^{\circ} \mathrm{C}\right)$ for $3.5 \mathrm{~h}$, and extracted with dichloromethane. Quantification was made in a gas chromatograph (CP-9001 Chrompack) equipped with a flame ionization detector. Fatty acids were separated on a TR-WAX (eq.CP-Sil $52 \mathrm{CB}$ ) $30 \mathrm{~m} \times 0.32 \mathrm{~mm} \times 0.25 \mu \mathrm{m}$ capillary column, using helium $(\mathrm{He})$ as carrier gas at a flow rate of $1.0 \mathrm{~mL}$ $\min ^{-1}$. Oven temperature was $50{ }^{\circ} \mathrm{C}$ for $2 \mathrm{~min}$, with a $10^{\circ} \mathrm{C}$ $\mathrm{min}^{-1}$ ramp to $225^{\circ} \mathrm{C}$ and with a final isothermal for $10 \mathrm{~min}$. Detector and injector temperatures were 250 and $220{ }^{\circ} \mathrm{C}$, respectively.

Specific Methanogenic Activity and Toxicity Assays. Specific methanogenic activity (SMA) was determined in batch assays with acetate $(30 \mathrm{mM})$ and $\mathrm{H}_{2} / \mathrm{CO}_{2}(80: 20 \mathrm{v} / \mathrm{v})$ as substrates. Toxicity tests were performed to evaluate the influence of sodium oleate, in concentrations up to $900 \mathrm{mg}$ $\mathrm{L}^{-1}$, on the methanogenic acetoclastic activity. The basal medium used in these experiments is described elsewhere (13) and vials were prepared with $2-5 \mathrm{~g} \mathrm{VS} \mathrm{L}^{-1}$. All batch tests were performed in triplicate and were incubated at 37 ${ }^{\circ} \mathrm{C}$ and $150 \mathrm{rpm}$. The methane content of the biogas was measured by gas chromatography, as described in the Routine Analysis section. Methane production values were corrected for STP conditions and initial methane production rate due to residual substrate consumption, measured in the blank controls, was subtracted.
Operation Mode. The reactor was operated in cycles during 213 days (Period I) and in continuous thereafter (Period II). During Period I, a total of five cycles was performed, by sequencing continuous feeding phases (F) and batch reaction phases (R), with OLR applied during feeding phases between 4.4 and $8.2 \mathrm{~kg} \mathrm{COD} \mathrm{m}^{-3} \mathrm{day}^{-1}$. After a reaction phase, feeding was restarted when biogas production, due to the degradation of the accumulated substrate, stopped. During the feeding phases, samples from the effluent were collected after the settler. In the reaction phases, samples were collected at the same point, representing the effluent that would be discharged at that time. With this procedure, the values obtained for soluble COD, VFA, and solids were considered to be comparable. During Period II, increasing OLR were applied continuously, from 5 to $31 \mathrm{~kg} \mathrm{COD} \mathrm{m}^{-3}$ day $^{-1}$, by decreasing the hydraulic retention time (HRT). OLR was increased only when COD removal efficiency was constant for more than 3 HRT and, simultaneously, the methane yield was higher than $60 \%$. Between the two operating periods, the sludge was stored at $4{ }^{\circ} \mathrm{C}$ for 30 days. During all of the experiment, the biomass present inside the reactor was purged periodically, to maintain a VS content around $20 \mathrm{~g} \mathrm{VS} \mathrm{L}^{-1}$.

\section{Results}

Period I: Operation in Cycles. The operating conditions applied during the experiment and the performance data are presented in Table 2. Details of these calculations are presented in the Supporting Information (eqs 1-3). An OLR of $4.4 \pm 0.6 \mathrm{~kg} \mathrm{COD} \mathrm{m}^{-3}$ day $^{-1}$ was applied over 17 days (phase F1), after which the reactor content was whitish and biogas production insignificant (data not shown), suggesting that substrate was not being completely degraded and was mainly accumulating inside the reactor. On the basis of these observations, feeding was stopped, giving place to the reaction-batch phase (R1). In the following two cycles (2nd and 3rd) a similar OLR was applied during a similar period of time (17 days).

Throughout Period I, COD was removed mainly in the feeding phases. Methane was produced mostly in the reaction phases during the first two cycles (more than $70 \%$ ), but in the third cycle $97 \%$ of the methane was produced in the feeding phase F3 (Table 2). On the basis of this result, the feeding phase time was increased in the fourth cycle (28 days), while applying the same OLR. In the fifth cycle, OLR was increased to $8.2 \pm 0.6 \mathrm{~kg} \mathrm{COD} \mathrm{m}^{-3}$ day $^{-1}$, maintaining a similar feeding phase time (22 days). Despite the changes in the applied operating conditions, the majority of the methane was produced again during the feeding phases (Table 2).

The shift in the methane production, from the feeding to the reaction phases, is clearly evidenced in Figure 1a, where the cumulative methane production during Period I is shown. The maximum plateau achieved in the cumulative methane production curves increased from the first to the third cycle 
TABLE 2. Operating Conditions and Performance Data ${ }^{a}$

\begin{tabular}{|c|c|c|c|c|c|c|c|c|c|}
\hline $\begin{array}{l}\text { period } \\
\text { operation mode }\end{array}$ & cycle & phase $^{a}$ & $\begin{array}{l}\text { time } \\
\text { (days) }\end{array}$ & $\begin{array}{l}\text { concentration } \\
\left(\mathrm{g} \mathrm{COD} \mathrm{L}^{-1}\right)\end{array}$ & HRT (days) & 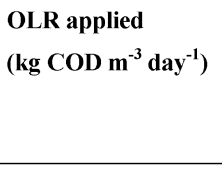 & $\begin{array}{l}\text { COD removal } \\
\text { efficiency }(\%)\end{array}$ & $\begin{array}{l}\text { phase to } \\
\text { cycle } \mathrm{CH}_{4} \\
\text { production } \\
\text { ratio }(\%)^{c}\end{array}$ & $\begin{array}{l}\text { methane } \\
\text { yield } \\
(\%)^{c}\end{array}$ \\
\hline \multirow[t]{11}{*}{ I cycles } & $1 \mathrm{st}$ & $\mathrm{F} 1$ & $0-17$ & $7.2 \pm 1.0$ & $1.60 \pm 0.01$ & $4.4 \pm 0.6$ & nd $^{b}$ & 24.2 & nd \\
\hline & & $\mathrm{R} 1$ & $17-45$ & 0 & & 0 & nd $^{b}$ & 75.8 & 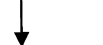 \\
\hline & 2nd & $\mathrm{F} 2$ & $45-62$ & $7.2 \pm 1.0$ & $1.60 \pm 0.01$ & $4.4 \pm 0.6$ & $68.0 \pm 11.0$ & 30.5 & 66.7 \\
\hline & & $\mathrm{R} 2$ & $62-100$ & 0 & & 0 & $3.2 \pm 0.4$ & 69.5 & $\downarrow$ \\
\hline & $3 \mathrm{rd}$ & $\mathrm{F} 3$ & $100-117$ & $7.2 \pm 1.0$ & $1.60 \pm 0.01$ & $4.4 \pm 0.6$ & $83.6 \pm 18.2$ & 96.7 & 72.7 \\
\hline & & R3 & $117-138$ & 0 & & 0 & $0.2 \pm 0.0$ & 3.3 & $\downarrow$ \\
\hline & 4th & $\mathrm{F} 4$ & $138-166$ & $7.2 \pm 1.0$ & $1.60 \pm 0.01$ & $4.4 \pm 0.6$ & $98.4 \pm 25.8$ & nd & $d$ \\
\hline & & R4 & $166-181$ & 0 & & 0 & $0.0 \pm 0.0$ & nd & $\frac{1}{\nabla}$ \\
\hline & 5 th & F5 & $181-203$ & $13.1 \pm 1.0$ & $1.60 \pm 0.01$ & $8.2 \pm 0.6$ & $97.0 \pm 7.1$ & 98.9 & 90.7 \\
\hline & & R5 & $203-213$ & 0 & & 0 & $0.0 \pm 0.0$ & 1.1 & $\downarrow$ \\
\hline & & & $213-243$ & storage at $4{ }^{\circ} \mathrm{C}$ & & & & & \\
\hline \multirow[t]{7}{*}{ II continuous } & & C-I & $243-277$ & $7.4 \pm 1.6$ & $1.50 \pm 0.10$ & $5.0 \pm 0.4$ & $77.3 \pm 19.1$ & & 81.5 \\
\hline & & C-II & $277-333$ & & $0.97 \pm 0.02$ & $7.8 \pm 1.0$ & $98.2 \pm 0.46$ & & 79.5 \\
\hline & & C-III & $333-389$ & & $0.72 \pm 0.01$ & $9.8 \pm 2.2$ & $98.7 \pm 0.38$ & & 86.0 \\
\hline & & C-IV & $389-437$ & & $0.49 \pm 0.03$ & $11.5 \pm 2.2$ & $99.0 \pm 0.42$ & & 98.4 \\
\hline & & $\mathrm{C}-\mathrm{V}$ & $437-571$ & & $0.37 \pm 0.01$ & $20.6 \pm 4.0$ & $98.6 \pm 0.76$ & & 71.5 \\
\hline & & $\mathrm{C}-\mathrm{VI}$ & $571-608$ & & $0.30 \pm 0.00$ & $26.1 \pm 4.2$ & $96.3 \pm 1.79$ & & 60.9 \\
\hline & & C-VII & $608-665$ & 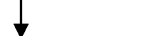 & $0.26 \pm 0.00$ & $31.2 \pm 7.9$ & $90.6 \pm 7.73$ & & 57.0 \\
\hline
\end{tabular}

${ }^{a}$ F, Feeding; R, Reaction; C, Continuous; nd, not determined. ${ }^{b}$ Standard deviation in the range of $\pm 10 \% .{ }^{c}$ Problems with the biogas counter.

and methane yields increased gradually from a minimum value of $67 \%$ to a maximum value of $91 \%$ (Table 2 ).

The maximum values measured for COD and VFA decreased from cycle to cycle and shifted from the feeding phases (1st and 2nd cycle) to the reaction phases (3rd cycle until the end of Period I). In the fifth cycle, soluble COD and VFA accumulation was negligible (Figure $1 \mathrm{~b}$ ). Although acetic and propionic acids were the main VFA quantified, it is relevant to note that iso-butyric and $n$-butyric acids were detected during the feeding phases of cycles 1 to 4 , in concentrations lower than $300 \mathrm{mg}$ COD L ${ }^{-1}$, and became insignificant during the reaction phases (Figure 2 of the Supporting Information). $n$-Butyric acid concentrations were higher than the iso form. Overall, COD removal efficiency increased gradually from cycle to cycle, from a minimum value of $71 \%$ to a maximum value around $98 \%$ in the last two cycles (Table 2).

To elucidate about LCFA accumulation in the system, fatty acids from $\mathrm{C} 12$ to $\mathrm{C} 18$ were quantified in the nine samples collected during Period I (Figure 1c). Accumulation onto the sludge was observed only during the first two cycles, reaching a maximum value of $1.7 \mathrm{~g}$ COD-LCFA $\mathrm{g} \mathrm{VS}^{-1}$. Accumulated LCFA were efficiently biodegraded during the reaction phase of the second cycle and in the third, fourth, and fifth cycles only residual amounts were detected (values lower than $0.06 \mathrm{~g} \mathrm{COD}$-LCFA g VS $^{-1}$ ). Palmitic and stearic acids were the dominant intermediates quantified (Figure 1c) and represented around $45-50 \%$ of total LCFA-COD each.

Samples 1 (inoculum), 7 (end of the third cycle), and 9 (end of Period I) were characterized in terms of SMA in the presence of acetate and $\mathrm{H}_{2} / \mathrm{CO}_{2}$ (Table 3). Increasing SMA values were obtained along the operation.
The results of the toxicity assays performed with sample 1 (Figure 2a) and sample 9 (Figure 2b) also evidence the increase in the specific methanogenic acetoclastic activity during Period I, as shown by the increase in the initial slopes of the cumulative methane production curves. Moreover, high tolerance of the acetoclastic methanogens to oleic acid toxicity was observed in both samples, since increasing the oleate concentrations did not induce a considerable reduction in the slope of the cumulative methane production curves relatively to the control. On sample 9, it was just for the concentration of $900 \mathrm{mg}$ oleate $\mathrm{L}^{-1}$ that a significant effect was observed, corresponding to a $61 \%$ reduction of the acetoclastic methanogenic activity.

Period II: Continuous Operation. Organic loading rates between 5 and $31 \mathrm{~kg} \mathrm{COD} \mathrm{m}^{-3}$ day $^{-1}$ were applied during Period II (phases C-I to C-VII, Table 2). Through the first 8 days of continuous operation, soluble COD values increased until $3000 \mathrm{mg} \mathrm{COD} \mathrm{L}^{-1}$ and COD removal efficiency decreased to $57 \%$, probably due to the storage of the sludge at $4{ }^{\circ} \mathrm{C}$ for 30 days between the two operating periods. Nevertheless, soon after, the system's performance improved: COD removal efficiency reached values higher than $96 \%$ after 30 days of operation, and averaged $99 \pm 0.6 \%$ throughout the OLR of 8 to $21 \mathrm{~kg} \mathrm{COD} \mathrm{m}^{-3}$ day $^{-1}$. When the OLR was increased to $31 \mathrm{~kg} \mathrm{COD} \mathrm{m}^{-3}$ day $^{-1}$, a steady decrease of the COD removal efficiency was observed, reaching a minimum value of $73 \%$. VFA values increased in the beginning of Period II and again in the last two phases of operation (Figure 3), with acetic and propionic acids as the main VFA quantified (Figure 3 of the Supporting Information).

A fast increase of the methane production rate, proportional to the applied OLR, was observed between 5 and 21 

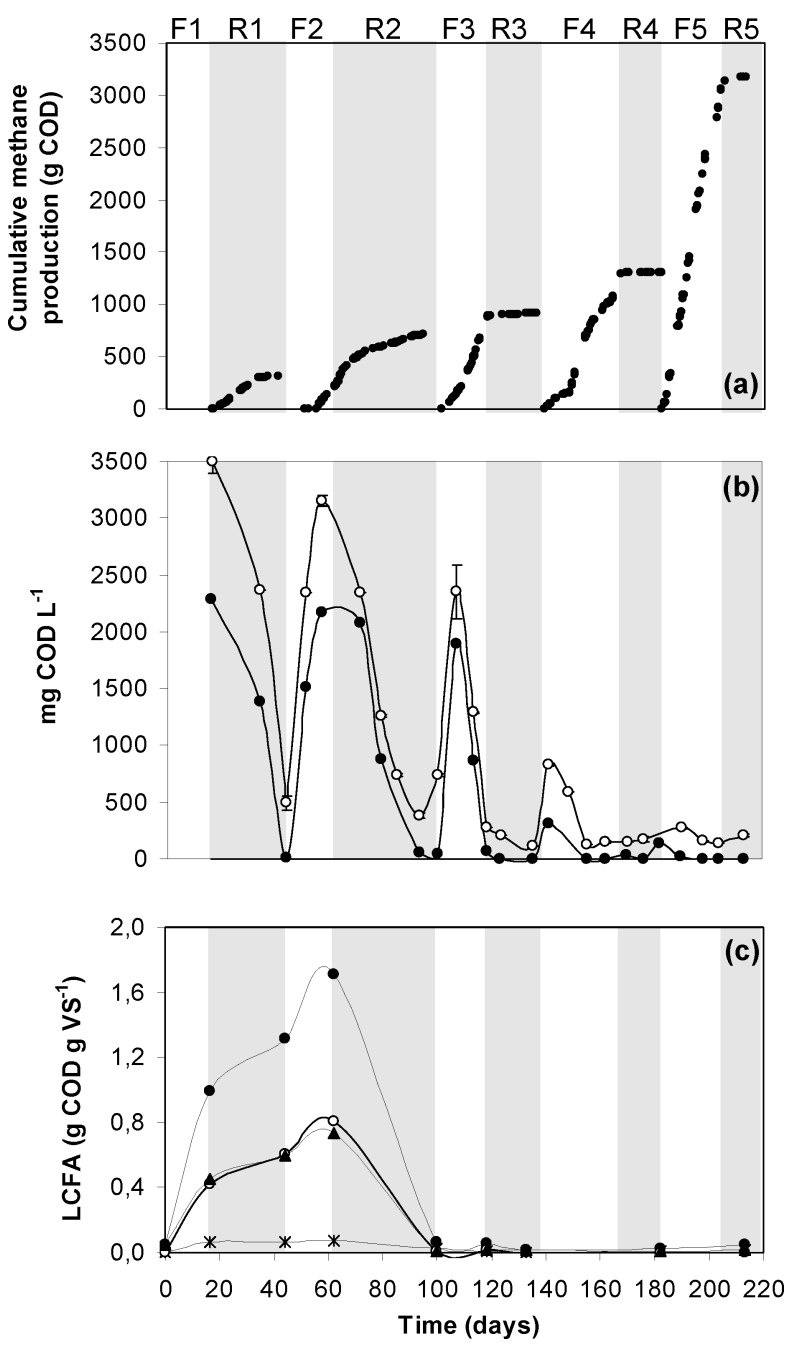

FIGURE 1. Performance data during Period I: (a) cumulative methane production; (b) soluble $\operatorname{COD}(O)$ and total VFA (O); (c) total LCFA (O), oleic acid C18:1 $\left({ }^{*}\right)$, stearic acid C18:0 $(O)$ and palmitic acid C16:0 (A). F (white), Feeding; R (gray), Reaction.

TABLE 3. Specific Methanogenic Activity (mg $\mathrm{COD}^{-\mathrm{CH}_{4}} \mathrm{gVS}^{-1}$ day ${ }^{-1}$ ) in the Presence of Acetate and $\mathrm{H}_{2} / \mathrm{CO}_{2}$

$\begin{array}{cccc}\begin{array}{c}\text { sample } \\ \text { no. }\end{array} & \begin{array}{c}\text { time } \\ \text { (days) }\end{array} & \begin{array}{c}\text { acetoclastic } \\ \text { activity }\end{array} & \begin{array}{c}\text { hydrogenotrophic } \\ \text { activity }\end{array} \\ 1 & 0 & \text { n.d. }^{a} & 159 \pm 18 \\ 7 & 138 & 512 \pm 52 & 1516 \pm 28 \\ 9 & 213 & 703 \pm 20 & 1462 \pm 68 \\ 18 & 665 & 1421 \pm 55 & 3777 \pm 497 \\ \text { a n.d. }- \text { non detected. } & & \end{array}$

$\mathrm{kg} \mathrm{COD} \mathrm{m}{ }^{-3}$ day $^{-1}$. However, when the OLR was increased to $26 \mathrm{~kg} \mathrm{COD} \mathrm{m}^{-3} \mathrm{day}^{-1}$, the methane production rate fluctuated around the same average value as in the previous phase (Figure 3). For the OLR of $31 \mathrm{~kg} \mathrm{COD} \mathrm{m}^{-3} \mathrm{day}^{-1}$, the methane production rate tended to decrease.

A maximum methane yield of $98.4 \%$ was obtained for the OLR of $12 \mathrm{~kg} \mathrm{COD} \mathrm{m}^{-3} \mathrm{day}^{-1}$, and from that period until the end of the operation the methane yields decreased until $57 \%$ (Table 2). For an OLR as high as $21 \mathrm{~kg} \mathrm{COD} \mathrm{m}^{-3} \mathrm{day}^{-1}, 72 \%$ of the COD removed was converted to methane.

No LCFA accumulation was observed in this period, with the exception of the last two OLR of 26 and $31 \mathrm{~kg} \mathrm{COD} \mathrm{m}^{-3}$ day $^{-1}$ (Figure 4a of the Supporting Information). Nevertheless, the amount of accumulated LCFA was always lower than 443 $\pm 36 \mathrm{mg}$ COD-LCFA g VS ${ }^{-1}$. Palmitic acid was the dominant
LCFA, representing $40-100 \%$ of all LCFA detected. Oleic acid $(0-28 \%)$, stearic acid (0-20\%) and myristic acid (3-20\%) were also present in the samples collected during Period II (Figure $4 \mathrm{~b}$ of the Supporting Information).

SMA measured at the end of the Period II evidenced an increase in the specific methanogenic activity, two times in the presence of acetate and three times in the presence of $\mathrm{H}_{2} / \mathrm{CO}_{2}$, relatively to the ones measured at the end of period I (Table 3).

\section{Discussion}

The feeding strategy and the experimental plan applied aimed to understand the sequencing of LCFA accumulation and degradation during a step feeding operation. However, surprisingly, only in the first two cycles was the expected accumulation and degradation sequence observed. The shift in the methane production from the feeding to the reaction phases, as well as the steady increase in the methane yield from 67 to $91 \%$, showed that the anaerobic consortium was acquiring the ability of continuously degrading the substrate rich in oleic acid and, consequently, it appeared that the batch-reaction phases were no longer necessary. COD and VFA patterns also showed an enhancement of the microbial community biodegradation capacity along the time. Alternatively, $n$-butyric and iso-butyric acids, detected during the feeding phases of cycles 1 to 3 , were good indicators of process imbalance, since these two VFA appear generally in very low concentrations during balanced anaerobic digestion and can accumulate rapidly when the process is disturbed (16). The fact that the concentration of these two VFA was very low or practically null in cycles 4 and 5 of Period I, and also during Period II, indicate that the system was not seriously disturbed, even for the highest OLR applied.

Increasing SMA values were obtained in the present work (Table 3), and the results of the toxicity assays showed high tolerance of the acetoclastic methanogens to oleic acid toxicity. Previous reports of Pereira et al. $(11,12)$ showed that, after allowing the degradation of the accumulated substrate in heavily LCFA-loaded sludge, the SMA was considerably enhanced. This finding suggested that cycles of continuous LCFA feeding, followed by batch degradation of the accumulated substrate, would solve the problem of the anaerobic mineralization of lipid-rich wastewater. However, the present work clearly demonstrates that sequencing feeding and degradation is only a prerequisite that should be applied for inoculum acclimation.

After the step feeding start-up, continuous operation was applied and the optimum OLR was assessed, aiming the maximization of the COD recovered as methane. The OLR was increased steadily from 5 to $21 \mathrm{~kg} \mathrm{COD} \mathrm{m}^{-3}$ day $^{-1}$ (phases $\mathrm{C}-\mathrm{I}$ to $\mathrm{C}-\mathrm{V}$ ) warranting very high COD removal efficiencies and methane yields higher than $72 \%$ (Table 2). In the last two phases of operation, when the OLR was increased to 26 and subsequently to $31 \mathrm{~kg} \mathrm{COD} \mathrm{m}^{-3} \mathrm{day}^{-1}$, the COD removal efficiency decreased, the methane production decreased and was more instable (Figure 3), suggesting that the applied OLR near $20 \mathrm{~kg} \mathrm{COD} \mathrm{m}^{-3}$ day $^{-1}$ should not be exceeded. At this OLR, there was no significant LCFA accumulation, but the methane yield was lower than expected from the COD removal efficiency data. This difference, which accounted for $28 \%$, can be explained in two possible ways: (1) a high growth rate of the anaerobic microorganisms and (2) a possible accumulation of substrates other than LCFA (sugar and proteins) in the sludge aggregates. Considering this last hypothesis, it should be mentioned that the samples analyzed for LCFA quantification were also incubated in batch vials, without any added carbon source, calcium, or nutrients, and the methane production due to the degradation of the accumulated substrate was recorded. For most of the samples, 

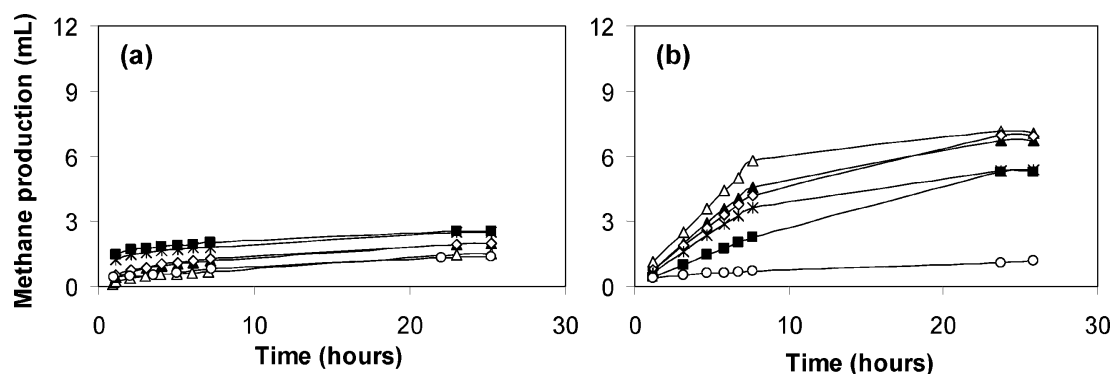

FIGURE 2. Cumulative methane production in the toxicity assays of oleate toward the methanogenic acetoclastic activity, for (a) sample 1 (inoculum), and (b) sample 9 (end of Period I). Blank assay without oleate or acetate (O); control assay with acetate and no oleate $(\Delta)$; assay with acetate and $300 \mathrm{mg} \mathrm{L}^{-1}$ of oleate $(\Delta)$; assay with acetate and $500 \mathrm{mg} \mathrm{L}^{-1}$ of oleate $(\diamond)$; assay with acetate and $700 \mathrm{mg} \mathrm{L}^{-1}$ of oleate $\left(^{*}\right)$; assay with acetate and $900 \mathrm{mg} \mathrm{L}^{-1}$ of oleate $(\square)$.

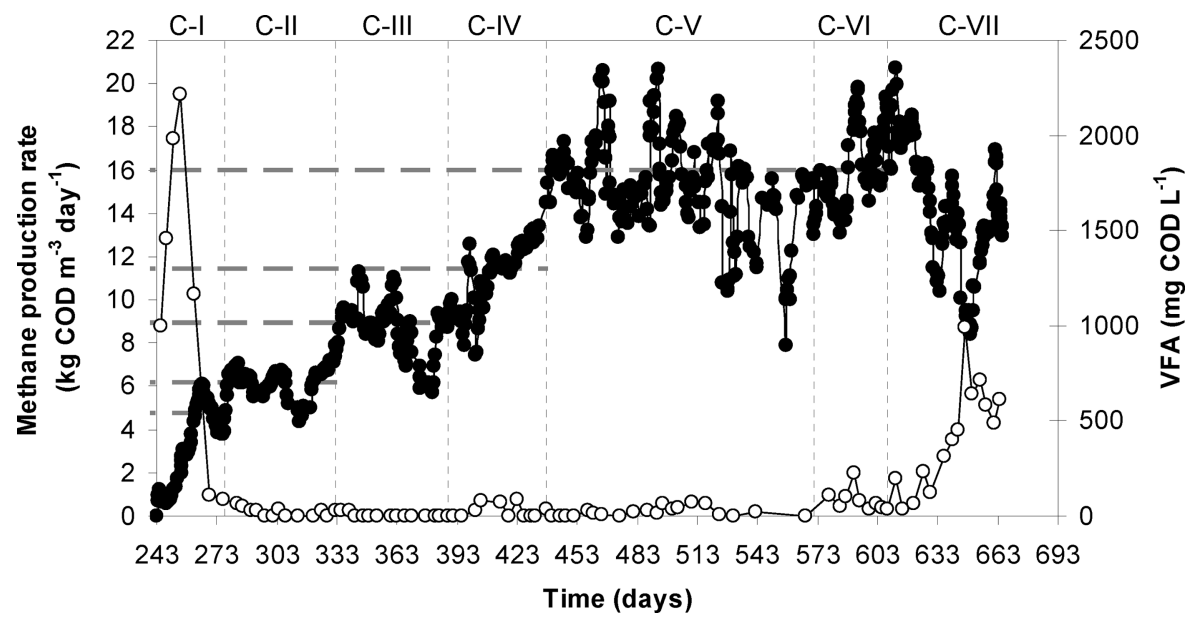

FIGURE 3. Methane production rate (๑) and total VFA (O) during Period II. (---) Average methane production rate.

the methane produced exceeded largely the amount that would originate from the accumulated LCFA (data not shown).

LCFA accumulation onto the sludge was only observed during the first two cycles, with stearic and palmitic acids as the main LCFA quantified (Figure 1c). The biochemical mechanism of anaerobic LCFA degradation is still unclear, especially the initial steps in the conversion of the unsaturated LCFA. While the degradation of saturated LCFA follows the classic $\beta$-oxidation pathway, the degradation of unsaturated LCFA might require a preliminary step of hydrogenation or an alternative degradation pathway (17). Palmitic acid (C16: 0 ) has been reported as the main intermediate detected during oleate (C18:1) degradation (18-20). According to Lalman and Bagley (18), the production of stearic and palmitic acid from oleic acid is energetically favorable $\left(\Delta G^{0^{\prime}}=-78.6\right.$ and $-27.8 \mathrm{~kJ} \mathrm{~mol}^{-1}$, respectively), but the production of palmitic acid from stearic acid is not $\left(\Delta G^{0^{\prime}}=+50.8 \mathrm{~kJ} \mathrm{~mol}^{-1}\right)$. If stearic acid is formed from oleic acid reduction, then it will be expected to transiently accumulate until environmental conditions change in order to allow its degradation. However, Broughton et al. (21) stated that a fermentation of oleate to palmitate analogous to crotonate fermentation by syntrophic acetogenic bacteria together with Clostridium kluyveri may explain the formation of stearic and palmitic acids, as shown by the equations presented in Table 2 of the Supporting Information, where reaction 3 is highly exergonic under standard conditions. During Period II of operation palmitic acid was the main LCFA quantified. This difference, relative to the accumulation of palmitic and stearic acids during Period I, can be due to the step feeding start-up applied that promoted sludge acclimation. Consequently, the microbial community structure and its major metabolic pathways can possibly have changed.
These results clearly show that there was no significant inhibition of the anaerobic microbial community, and good LCFA degradation capacity was confirmed by the negligible quantities of VFA and LCFA quantified throughout the periods of applied OLR of 5 to $21 \mathrm{~kg} \mathrm{COD} \mathrm{m}^{-3} \mathrm{day}^{-1}$. Even when applying the highest loads, the VFA and LCFA levels did not

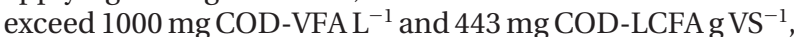
respectively, suggesting that the biodegradation capacity of the anaerobic consortium was not seriously compromised. Indeed, for the OLR of $31 \mathrm{~kg} \mathrm{COD} \mathrm{m}^{-3} \mathrm{day}^{-1}$, still $73 \%$ of COD removal efficiency and a methane yield of $57 \%$ were achieved.

During the reactor's operation, the specific methane production rate was calculated considering the methane production rate (g COD- $\mathrm{CH}_{4}$ day $^{-1}$ ) and the levels of VS measured periodically inside the reactor. Maximum values of $1170 \pm 170$ and $1090 \pm 220 \mathrm{mg} \mathrm{COD}-\mathrm{CH}_{4} \mathrm{~g} \mathrm{VS}^{-1} \mathrm{day}^{-1}$ were attained in the last two phases of operation, when the applied OLR was 26 and $31 \mathrm{~kg} \mathrm{COD} \mathrm{m}^{-3}$ day $^{-1}$, respectively. The maximum value reported up to date in the literature for oleate as substrate is $600 \mathrm{mg}$ COD-CH $\mathrm{gVS}^{-1} \mathrm{day}^{-1}$ (9), which is around $50 \%$ of the obtained in the present work. This evidenced the very high capacity of the anaerobic community developed inside the reactor to degrade the oleate based effluent. A comparison with other studies reported in the literature for lipid or LCFA-rich wastewater treatment $(2-7)$ shows that to date these are the best results reported in terms of applied OLR and corresponding methane yields, with attained values as high as $98 \%$ and $72 \%$ for OLR of $12 \mathrm{~kg}$ COD $\mathrm{m}^{-3}$ day $^{-1}$ and $21 \mathrm{~kg} \mathrm{COD} \mathrm{m}^{-3} \mathrm{day}^{-1}$, respectively.

This work represents an important step forward in the anaerobic digestion of LCFA based effluents, since it demonstrates that a step feeding start-up promotes sludge acclimation and is conducive to the development of an anaerobic microbial community able to efficiently mineralize 
LCFA. Feasibility of high rate treatment processes for complex wastewater with lipids was proven for the first time.

\section{Acknowledgments}

The authors thank to Lúcia Neves, Carla Ferreira, Celina Dias, Filipa Pereira, and Jorge Cunha for their contribution in the experimental work, and to Diana Sousa for her scientific support. Financial support from the European Commission through the project Life-Environment EMAS@SCHOOL (LIFE03 ENV/P/000501) and from Fundação para a Ciência e a Tecnologia (FCT), through the projects FAT-METHANE (POCTI/CTA/46328/2002) BIOPOWER (PTDC/BIO/69745/ 2006), and the $\mathrm{PhD}$ grant $\mathrm{SFRH} / 24256 / 2005$, is gratefully acknowledged.

\section{Supporting Information Available}

Calculation details on COD removal efficiency, phase to cycle methane production ratio and methane yield; schematic representation of the experimental setup; VFA during Periods I and II of operation; LCFA accumulation onto the sludge during Period II; sampling during the experiment; Gibbs free energy values for the (possible) reactions of stearic and palmitic acid formation from oleic acid. This information is available free of charge via the Internet at http:/ / pubs.acs.org.

\section{Literature Cited}

(1) Hwu, C-S.; Tseng, S-K.; Yuan, C-Y.; Kulik, Z.; Lettinga, G. Biosorption of long-chain fatty acids in UASB treatment process. Water Res. 1998, 32, 1571-1579.

(2) Kim, S-H.; Han, S-K.; Shin, H-S. Two-phase anaerobic treatment system for fat-containing wastewater. J. Chem. Technol. Biotechnol. 2004, 79, 63-71.

(3) Jeganathan, J.; Nakhla, G.; Bassi, A. Long-term performance of high-rate anaerobic reactors for the treatment of oily wastewater. Environ. Sci. Technol. 2006, 40, 6466-6472.

(4) Hwu, C-S.; van Lier, J. B.; Lettinga, G. Physicochemical and biological performance of expanded granular sludge bed reactors treating long-chain fatty acids. Process Biochem. 1998, 33, 75-81.

(5) Pereira, M. A.; Mota, M.; Alves, M. M. Operation of an anaerobic filter and an EGSB reactor for the treatment of an oleic acidbased effluent: influence of inoculum quality. Process Biochem. 2002, 37, 1025-1031.

(6) Palenzuela-Rollon, A.; Zeeman, G.; Lubberding, H. J.; Lettinga, G.; Alaerts, G. J. Treatment of fish processing wastewater in a one- or two-step upflow anaerobic sludge blanket (UASB) reactor. Water Sci. Technol. 2002, 45, 207-212.

(7) Rinzema, A. Anaerobic Treatment of Wastewater with High Concentrations of Lipids and Sulfate, $\mathrm{PhD}$ thesis; Wageningen Agricultural University: Wageningen, The Netherlands, 1988.
(8) Sousa, D. Z. Ecology and Physiology of Anaerobic Microbial Communities That Degrade Long Chain Fatty Acids, $\mathrm{PhD}$ thesis; Universidade do Minho: Braga, Portugal; 2007. Available at http://repositorium.sdum.uminho.pt/handle/1822/6287.

(9) Hwu, C-S. Enhancing Anaerobic Treatment of Wastewaters Containing Oleic Acid, $\mathrm{PhD}$ thesis; Wageningen Agricultural University: Wageningen, The Netherlands, 1997.

(10) Tagawa, T.; Takahashi, H.; Sekiguchi, Y.; Ohashi, A.; Harada, H. Pilot-plant study on anaerobic treatment of a lipid- and proteinrich food industrial wastewater by a thermophilic multi-staged UASB reactor. Water Sci. Technol. 2002, 45, 225-230.

(11) Pereira, M. A.; Pires, O. C.; Mota, M.; Alves, M. M. Anaerobic biodegradation of oleic and palmitic acids: evidence of mass transfer limitations caused by long chain fatty acid accumulation onto the anaerobic sludge. Biotechnol. Bioeng. 2005, 92, 15-23.

(12) Pereira, M. A; Sousa, D. Z.; Mota, M.; Alves, M. M. Mineralization of LCFA associated with anaerobic sludge: kinetics, enhancement of methanogenic activity, and effect of VFA. Biotechnol. Bioeng. 2004, 88, 502-511.

(13) Alves, M. M.; Mota Vieira, J. A.; Álvares Pereira, R. M.; Pereira, M. A.; Mota, M. Effects of lipids and oleic acid on biomass development in anaerobic fixed-bed reactors. Part II: Oleic acid toxicity and biodegradability. Water Res. 2001, 35, 264-270.

(14) APHA/AWWA/WEF In Standard Methods for the Examination of Water and Wastewater, 20th ed.; American Public Health Association/American Water Works Association/Water Environment Federation: Washington DC, USA, 1998.

(15) Neves, L.; Pereira, M. A.; Mota, M.; Alves, M. M. Detection and quantification of long chain fatty acids in liquid and solid samples and its relevance to understand anaerobic digestion of lipids. Bioresour. Technol. 2009, 100, 91-96.

(16) Ahring, B. K.; Sandberg, M.; Angelidaki, I. Volatile fatty acids as indicators of process imbalance in anaerobic digesters. Appl. Microbiol. Biotechnol. 1995, 43, 559-565.

(17) Sousa, D. Z.; Smidt, H.; Alves, M. M.; Stams, A. J. Ecophysiology of syntrophic communities that degrade saturated and unsaturated long-chain fatty acids. FEMS Microbiol. Ecol. 2009. Submitted for publication.

(18) Lalman, J. A.; Bagley, D. M. Anaerobic degradation and methanogenic inhibitory effects of oleic and stearic acids. Water Res. 2001, 35, 2975-2983.

(19) Salminen, E.; Einola, J.; Rintala, J. Characterization and anaerobic batch degradation of materials accumulating in anaerobic digesters treating poultry slaughterhouse waste. Environ. Technol. 2001, 22, 577-585.

(20) Pereira, M. A.; Pires, O. C.; Mota, M.; Alves, M. M. Anaerobic degradation of oleic acid by suspended and granular sludge: identification of palmitic acid as a key intermediate. Wat. Sci. Technol. 2002, 45, 139-144.

(21) Broughton, M. J.; Thiele, J. H.; Birch, E. J.; Cohen, A. Anaerobic batch digestion of sheep tallow. Water Res. 1998, 32, 1423-1428.

ES8031264 